\title{
FINANCIAL RESOURCES MANAGEMENT AT THE LEVEL OF THE EUROPEAN UNION AND ROMANIA
}

\author{
Roxana SÂRBU ${ }^{a}$, Amelia DIACONU ${ }^{b}$ \\ Victor Adrian TROACA ${ }^{c *}$, Victor Marian DUMITRACHE ${ }^{d}$ \\ a, c, d, Bucharest University of Economic Studies, Romania \\ ${ }^{b}$ Artifex University of Bucharest, Romania
}

\section{ABSTRACT:}

Taxation plays a key role in creating a fair society and building a strong economy. Through it, progress can be made towards eliminating inequalities, not only by supporting social mobility, but also by reducing inequalities in market income. Fiscal policy can also have a major influence on employment decisions, investment levels and the willingness of entrepreneurs to expand their business, all of which leads to stronger economic growth. This article aims to perform an analysis based on economic indicators on financial resources in the EU and Romania from the perspective of sustainable management.

KEYWORDS: economical efects, economical growth, social efects, unemployment

\section{INTRODUCTION}

For a normal development of the modern society, material, foreign exchange, human, informational resources are needed, but also financial resources, which have a major importance (Secareanu \& Tudorache, 2006). In a modern society, the need for financial resources is often outweighed by the rapidly growing demand (Jianu et al., 2019). And for a company to function well, it is important to collect sufficient financial resources in an appropriate way, along with allocating and using them efficiently and effectively. The importance of financial resources in a state's economy is mainly represented by the way it chooses to constitute them (Burlacu et al., 2019). This can have major repercussions on the distribution of income in the economy (Andreeva et. al., 2019).

Public financial resources can be defined as the totality of funds that are managed by public authorities to perform their functions and tasks (Bodislav et al., 2020). This ensures the functioning of the appropriate organizational structures represented by central and local public institutions, state-owned enterprises, etc. (Profiroiu et al., 2019). The public financial resources are made up of the resources of the central and local administration, the resources necessary for the protection and state social insurance and the resources of the autonomous public institutions and authorities.

Public financial resources, in their constitution can be influenced by several factors such as: economic factors (imprints a certain evolution of the gross domestic product that determines, in most cases, the increase of taxable income); monetary factors (interest, credit, money supply, rising prices, for example, lead to increased resources from taxes and fees); social factors (these involve the redistribution of resources to meet the needs of education, protection and social security), demographic factors (under certain conditions these factors influence the population and increase the number of taxpayers), political and military factors (through and financial implications, increase production and incomes, increases social security contributions, increases taxation, while influencing the level of public financial resources) and financial factors (Filip, 2003).

Extraordinary public financial resources are non-permanent, which implies their presence only in budget years and their absence in other years (Ken et al., 2003). The extraordinary character of the use of this category of resources is the consequence of the manifestation of some unusual,

\footnotetext{
${ }^{*}$ Corresponding author. E-mail address: adrian.troaca@gmail.com
} 
exceptional economic-social phenomena or situations, generating public needs (Rădulescu et al., 2018). They are usually represented by expenses imposed by extraordinary circumstances at one time or another, in which resources are currently possible but insufficient. This category may include government loans and currency issues (Brezeanu \& Simon, 2005).

\section{LITERATURE REVIEW}

Within Europe, it is noted that the first European initiative is linked to the adoption of the first EU Sustainable Development Strategy (EU SDS) by the Gothenburg European Council in 2001. The turning point for sustainable development in the EU was considered to have been reached in 2006. Climate change and energy consumption were then recognized as a threat to social and economic life, as well as national security (Bečić et al., 2012). In fact, some research claims that life cycle sustainability assessment (LCSA) has emerged as a methodology. This would allow a detailed representation of technologies in their processes from a life cycle perspective. A plausible indicator would be required to perform a deep LCSA. In their work, LCSA indicators are selected based on the SDGs. The implication of selection based on general objectives and the level of SDG indicators is compared in a first approach. The applicability of this selection is then tested by a case study (eg electrolytic hydrogen production). The analyzes are interesting showing significant differences between objective-based evaluation and indicator-based evaluation (Wulf et al., 2018).

On the other hand, recent studies show that Euroscepticism is on the rise in the European Union (EU). These leave open questions about what citizens expect to gain from EU membership and what could influence their dissent for EU integration. They analyze the EU's structural funds, which are considered to be one of the largest and most visible expenditure items in the EU budget. Surprising could be the conclusions of the study which finds that, through causal evidence, EU money does not influence citizens' support for the EU. However, the analysis shows that EU funds mitigate Euroscepticism when associated with tangible improvements in local labor market conditions. the ultimate goal of this form of EU intervention (Crescenzi et al., 2020).

In the context of global challenges, a number of papers are published presenting an overview of progress in the development of sustainable development indicators (SDIs). For example, some works have area-specific features such as Croatia and Slovenia. The analysis of indicators is usually based on national SDI sets.

Changing the paradigm, we identify more and more studies that capture the disruption of many companies across the European Union mainly due to the massive contagion of the new coronavirus (Covid-19). The pandemic has also led to a huge impact on revenue and cash flows that could lead to a significant increase in corporate bankruptcies. Researchers who investigated the impact of Covid-19 on the solvency profile of companies in EU member states have introduced multiple stress scenarios on financially listed companies. Their findings showed a gradual increase in the probability of default, an increase in debt repayment and a decrease in coverage. The results indicated that the solvency profile of all companies is deteriorating. The findings certify that the manufacturing, mining and retail sectors have become the most vulnerable to declining market capitalization coupled with a reduction in sales revenue. Their recommendations suggest that a tax deferral could be sufficient for a moderate deterioration in economic conditions. However, in the event of an exacerbation of trade shocks, it recommends hybrid support through debt and equity to avoid a possible crisis (Mirza et al., 2020).

Regarding the management of financial resources in the European Union, there are works that examine some of the new trends in EU financial regulation with a direct impact on the execution of the EU budget. One of them is considered to be the new EU financial regulation, valid from 01.01.2013.

This would allow a more efficient use of its own resources and establish simpler rules and clearer implementation procedures for beneficiaries. It was considered that in this way easier, faster and full access to Community funds would be possible. This access would allow the EU budget to play 
its role in stabilizing the Union. In order to increase their financial impact, various instruments are being analyzed and proposed, such as loans, equity or guarantees, which would improve the efficiency of EU funds (Sabău-Popa \& Mara, 2015).

\section{FINDINGS}

\subsection{Specific aspects regarding taxation in the member countries of the European Union}

The European Union is, as a whole, an area with high taxes (Minea \& Costas, 2006). In 2018, the value of taxes and social security contributions in 27 Member States amounted to 39.8\% of the weighted average GDP, with more than a third above the levels recorded in the United States and Japan. The level of taxation in the EU is high, not only compared to the two countries, but also compared to other economies in general (Brasoveanu, 2009). Although there is a high general level of taxation, 11 Member States are below the 35\% barrier of Gross Domestic Product, highlighting rather large differences in the tax rate between Member States. The differences between the taxation levels reach $20 \%$ of GDP (29\% of GDP in Romania compared to $46.3 \%$ of GDP in Denmark).

The Nordic countries (46.3\%) are in the group of states that manage to mobilize over 40\% of GDP as tax revenue. Denmark (46.2\%) and Finland (43.3\%), respectively Austria, Belgium, Italy and France, the latter registering a tax between $42.8 \%$ and $44.3 \%$.

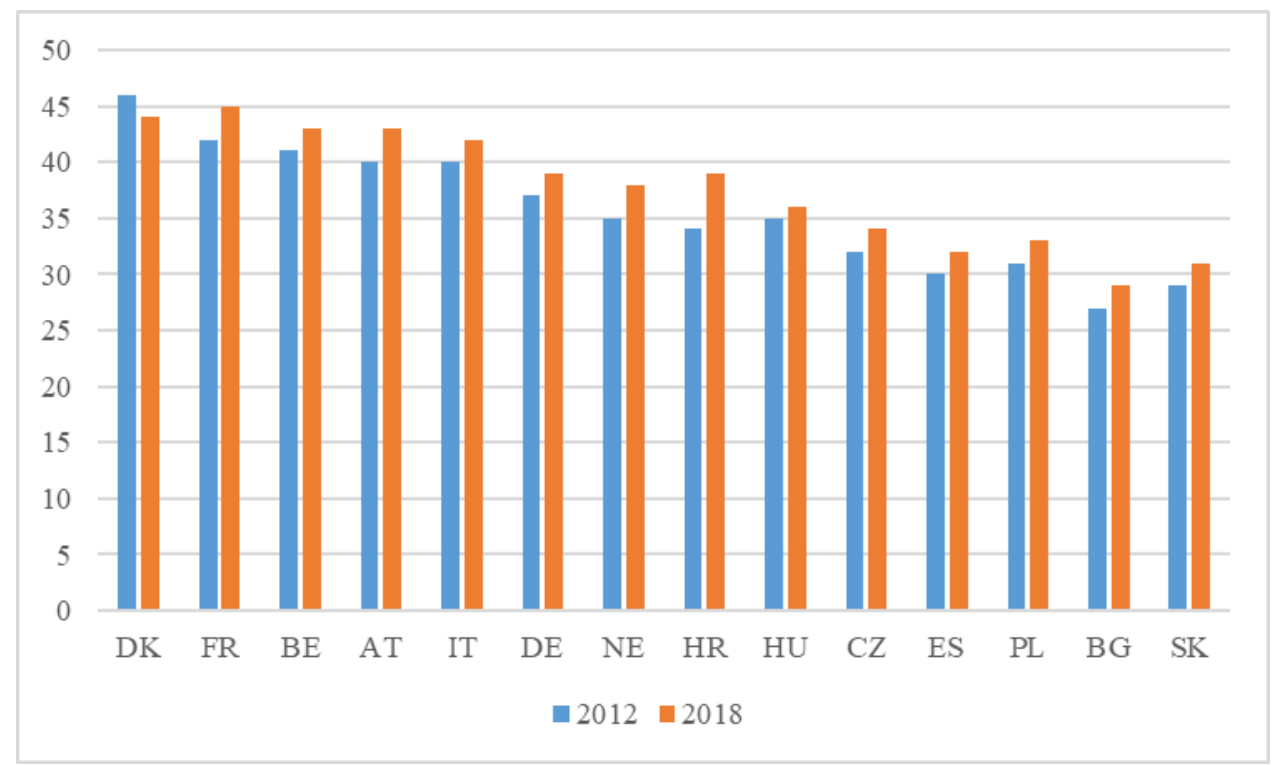

Figure 1- Tax rate in EU member states

Source: Eurostat, 2020

These major differences depend mainly on the differences between taxpayers 'incomes and their countries' GDPs. (Colin \& Greg, 2007). Technical factors also play an important role, for example some states provide social or economic assistance through tax cuts to the detriment of direct budget expenditures. Analyzing all 27 EU Member States for the period 1995-2008, the absolute maximum was reached by Sweden in 2000 and was 53.4\%, while the minimum was recorded in 1998 in Malta and was 25, 2\%. In Belgium, Finland, Sweden and Denmark, the share of direct taxes in GDP exceeds $15 \%$, being countries with a high taxation of personal income.

In first place is Denmark, and the second position is occupied by Sweden. In the last places are Estonia and Latvia with low values of the share of direct taxes in GDP.

The largest decreases were recorded in Bulgaria (6.1\%), Slovakia (5.7\%); however, significant reductions were also recorded in Poland, Estonia and Luxembourg. On the other hand, there were also increases of this indicator in Malta (3.8\%), France (3.6\%), Slovenia (2.3\%) and Cyprus (2.2\%). 


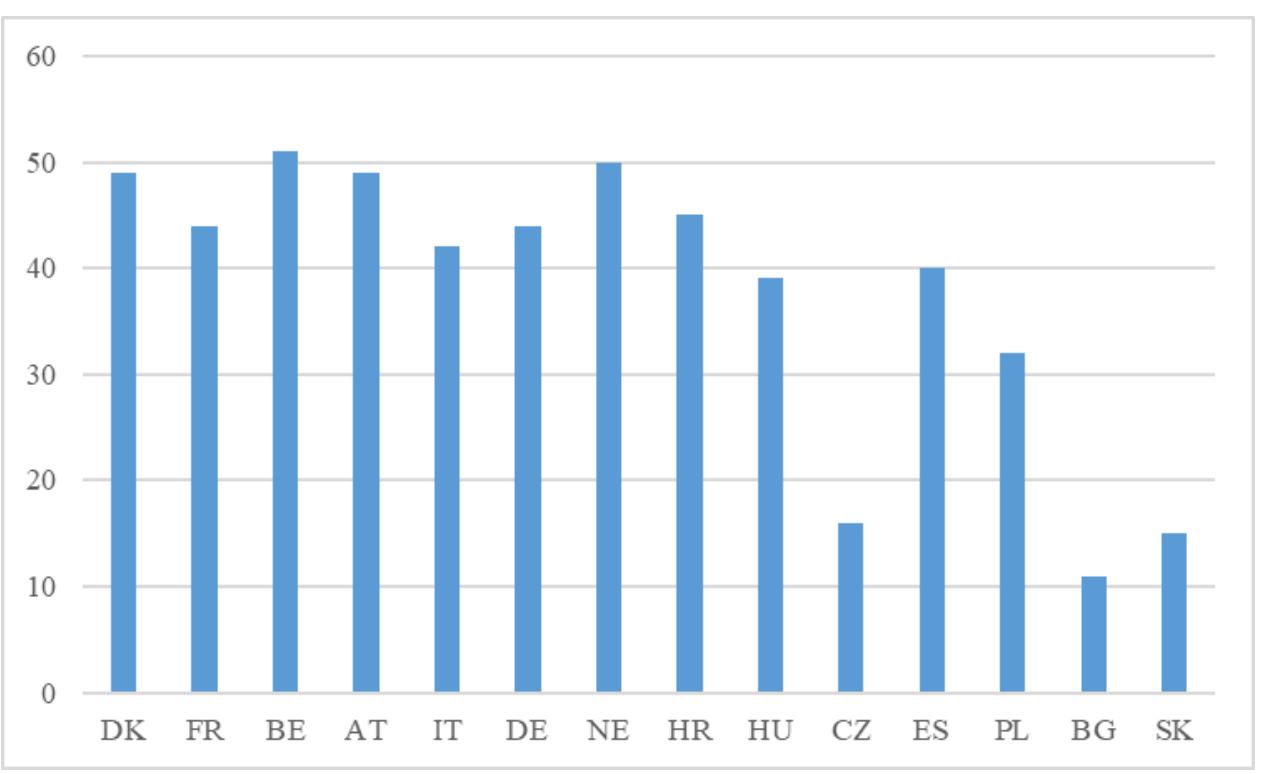

Figure 1: Impozitul pe veniturile persoanelor fizice în ţările membre UE, 2018

Source: Eurostat, 2019

In general, EU Member States have tax rates above 38\%, with only eight states having a tax rate of $30 \%$ or less. Among the countries that apply progressive tax rates are the Nordic countries that register at the same time the highest taxation of this tax. In Denmark, the tax mechanism is complex, with a maximum share of $53 \%$. In Sweden the maximum tax rate is $57.5 \%$, while in Finland there are five tax rates, ranging from $9 \%$ to $50 \%$ for incomes exceeding 85,000 euros.

\subsection{Local budget resources in European Union member countries}

All European Union countries have adopted the European Charter of Local Self-Government which aims to apply the principle of local self-government (Cazan-Balasa, 2016). At the same time, the very existence of the Union implies harmonization, including at the level of local public administrations. Thus, the local public budgets of the member countries of the European Union have similarities, but also small differences in structure. Some countries have a single budget, which is divided into two sections (operational and investment), while some countries have two separate local budgets, one operational and one investment.

According to the European Charter of Local Self-Government, the financial resources of local public authorities are divided into two categories:

- Own resources (are those resources that are controlled by local authorities according to the law and come from the jurisdiction of the local authority in the form of local taxes, fees for services provided or property income)

- Resources transferred from the central level (financial transfers) (these take the form of tax actions, general grants and specific grants).

In the countries of the European Union, local tax reforms aim to identify the most efficient form of administration of the local community. Reforms that took into account local taxes and fees were numerous and focused on the economic situation of each country.

Some measures taken during that period were to reduce the level of transfers of funds from the state from taxes to local authorities (eg Finland), to increase the level of taxes distributed from the central to the local level (eg France, Italy, Poland, Slovakia, Spain), initiation of new taxes (eg Estonia, Hungary and Italy), initiation of new local business tax reforms (eg France, Germany, Italy). 
Most local public administrations in European Union countries have their own revenues, so they have a different financial autonomy. The higher one's own income, the greater the degree of financial autonomy. Most income comes from taxes on wealth or property, or from the provision of services (for example, car parks).

In most European Union countries, including Romania, the most important source of own income is the property tax. The exception is Portugal, where real estate tax accounts for $40 \%$ of local tax revenue. Therefore, we can say that each government of the Member States of the European Union adopts its own fiscal policies, but they must not violate the principles underlying the establishment of the European Union. In terms of the tax rate, less developed countries are characterized by a lower tax rate, but the European Community as a whole remains an area with high taxation, compared to countries such as the United States and Japan.

\subsection{Dimension of public financial resources in Romania}

According to the annual report made by the World Bank, the number of taxes to be paid by companies each year places Romania on the 2nd place in the world. Another negative point highlighted by this report is the frequent changes in the tax system. According to the Fiscal Code, the scope of profit tax includes entities represented by persons or individuals associated with them who, following their activity, make a profit in Romania and abroad (Anghelache \& Belean, 2003).

The subjects of income tax are represented by all individuals, being an individual tax, because it is taxed separately for each person who obtained income from different sources. When several incomes are obtained jointly by several persons and cannot be individualized, taxation is applied to all persons who participated in the realization of these incomes (for example, the agricultural tax, where it is difficult to realize the individual taxation (Tatoiu, 2008).

The scope of income tax is represented by cash income as well as by the equivalent in lei of income in kind (equivalent to the benefit such as payment in kind) obtained by individuals, as well as any benefits (benefits received as a result of a contract between parts that do not represent the equivalent value of the work performed) received free of charge or with partial payment but also the personal use of the goods and rights related to the activity.

The taxable period is represented by the fiscal year, which corresponds to the calendar year, unless the taxpayer's death is recorded. In this case, the taxable period becomes shorter than the calendar year (Vacarel, 2006). The annual tax due by taxpayers is set by the tax authority and not by the taxpayer. However, the taxed body takes into account the taxpayer's declaration regarding the realized income. as a result, the tax authority issues a taxation decision, and the remaining unpaid differences will be extinguished within 60 days from the date of communication of the decision.

Taxpayers can deduct a series of income from the payment of income tax. This category includes income from salaries made by people with severe disabilities or income from salaries as a result of the creation of "software" programs, as well as savings expenses in a collective housing system up to 300 RON per year.

\subsection{Resources of the social insurance budget in Romania}

In Romania, social insurance appeared in the early 1900s, with the development of production processes, leading in time to the creation of the national social insurance system. The state social insurance budget is defined as the annual financial plan that reflects the establishment, distribution and use of funds necessary to protect employees and their families, as well as retirees. Until 1990, the social security budget was a chapter of the state budget, becoming autonomous after that date, its funds being used entirely to protect state citizens. If a surplus was recorded in one year, it was carried over to the following years (Voinea, 2005).

The state social insurance budget consists mainly of contributions from companies and public institutions, but also of individual contributions paid by insured persons, contributions of 
individuals using paid work, contributions of employees and pensioners for treatment tickets, bank interest, fines and penalties received and recovery of amounts unduly granted, etc.

The payment of the contributions is made by the paying units after deducting the amounts that represent the social insurance rights that are due to their own employees. This contribution represents a public financial reserve, and if it is not paid on time, delay increases are added, which can lead to forced execution. (Hieu \& Nwachukwu, 2020).

Consequently, we can say that Romania is in the group of states with a taxation below the European Union average, this fact being mainly due to the practice of the single tax rate of $16 \%$, which is a beneficial thing for attracting new investments. But one negative thing is the large number of taxes that have to be paid by companies, which places our country in 2nd place in the world according to the World Bank and the frequent changes in the legislative tax system.

\section{CONCLUSIONS}

Public financial resources represent the total funds administered by public authorities in order to meet the needs of public consumption, being characterized by the fact that they belong to the state. Public financial resources include resources available to central authorities (taxes, fees and general contributions) and local authorities (taxes, fees and local contributions), budgetary resources of social and state insurance (social security contributions) and resources of public authorities and selfemployed institutions character. The constitution of public financial resources is affected by a number of economic, monetary, social, demographic, political, military, as well as financial factors. The overall tax rate has fallen since 2000, but on average only for a few years, due at least in part to the need for more countries to reduce the general government deficit.

Although there is a high general level of taxation, 11 Member States are below the $35 \%$ barrier of gross domestic product, showing quite large differences in the tax rate between Member States. The differences between tax levels reach 20\% of GDP (28\% of GDP in Romania, compared to $48.2 \%$ of GDP in Denmark). In the group of states that manage to mobilize over $40 \%$ of GDP as tax revenue are the Nordic countries Sweden (47.1\%). Denmark (48.2\%) and Finland (43.1\%), respectively Austria, Belgium, Italy and France, the latter registering a tax between $42.8 \%$ and $44.3 \%$. In the group of states that collect less than 30\% of GDP in the form of tax revenues are still close to Romania, Slovakia and Lithuania, while Estonia and Lithuania are slightly above this threshold. One explanation for this is the practice of a single rate of income tax.

These major differences depend mainly on the differences between taxpayers' incomes and their GDPs, but also on how some states choose to provide some benefits to the population, as well as the level of the "black" economy, manifests itself through tax evasion.

In the case of indirect taxes, we note that Bulgaria is the country with the highest share of GDP in $19.3 \%$, and the Czech Republic has the lowest share of $11 \%$. Sweden, Denmark, Cyprus and Bulgaria are at the opposite pole and have a share of over $17 \%$ of GDP. Romania has a low share of indirect taxes in GDP, of only 12.4\%, being close to the minimum registered in EU countries.

In conclusion, we can say that in the member countries of the European Union, the formation of financial resources available to central and local public authorities, has led to a high taxation compared to the situation in other economies, at least as developed as the United States, Japan or New Zealand.

\section{REFERENCES:}

Andreeva, T., Popova, L., Yashina, M. (2019). Integration of the Quality Management and Strategic Management Systems into Unified Management System of Enterprises. Quaity-Access to Success, 20(171).

Anghelache, G. \& Belean, P. (2003). Finanţele Publice ale României. Bucharest: Editura Economică. 
Bečić, E., Mulej, E. M., \& Švarc, J. (2012). Measuring Social Progress by Sustainable Development Indicators: Cases of Croatia and Slovenia. Procedia - Social and Behavioral Sciences, 37, 458465.

Bodislav, D.A., Radulescu, C.V., Bran, F. \& Burlacu, S. (2020). Public Policy in the Areas of Environment and Energy. Paper presented at 6th BASIQ International Conference on New Trends in Sustainable Business and Consumption. Messina, Italy.

Brasoveanu, I.V. (2009). Analize ale politicii fiscale în România şi în statele membre a UE. Bucharest, Romania: Editura ASE.

Brezeanu, P. \& Simon, I. (2005). Fiscalitatea Europeană. Bucharest, Romania: Editura Economică.

Burlacu, S., Profiroiu, A., \& Vasilache, P. C. (2019). Impact of Demography on the Public Finance of the European Union. Calitatea, 20(S2), 136-138.

Cazan-Balasa, M. (2016). Politici Și Strategii Privind Securitatea Internă in Cadrul UE. Proceedings of Scientific Conference "New Challenges related to EU`s Internal Security", Bucharest, Romania.

Colin, R. \& Greg, N.G. (2007). International Taxation Handbook-Policy, Practice, Standards, and Regulation. Burlington, MA: Cima Publishing.

Crescenzi, R., Di Cataldo, M., \& Giua, M. (2020). It’s not about the money. EU funds, local opportunities, and Euroscepticism. Regional Science and Urban Economics, 84.

Filip, G. (2003). Finanţe Publice. Iași, Romania: Editura Sedcom Libris.

Hieu, V.M. \& Nwachukwu, C. (2020). Human Resources, Financial Resources and Strategic Performance: Organisational Policy as Moderator. Quality-Access to Success, 21(175).

Jianu, I., Dobre, I., Bodislav, D. A., Radulescu, C. V., \& Burlacu, S. (2019). The Implications of Institutional Specificities on the Income Inequalities Drivers in European Union. Economic Computation and Economic Cybernetics Studies and Research, 53(2), 59-76.

Ken, M., Flip, K., Christopher H. (2003). Tax Policy-Theory and Practice in OECD Countries. New York, NY: Oxford University Press.

Minea, M.S. \& Costas, C.F. (2006). Fiscalitatea în Europa mileniului III. Bucharest, Romania: Editura Rosetti.

Mirza, N., Rahat, B., Naqvi, B., \& Rizvi, S. K. A. (2020). Impact of Covid-19 on corporate solvency and possible policy responses in the EU. Quarterly Review of Economics and Finance.

Profiroiu, A., Burlacu, S., \& Sabie, O. (2019). Reform of the Pension System in Romania. Calitatea, 20(S2), 521-524.

Rădulescu, C. V., Dobrea, R. C., \& Burlacu, S. (2018). The Business Management of Distress Situations. Paper presented at the 12th INTERNATIONAL MANAGEMENT CONFERENCE "Management Perspectives in the Digital Era". Bucharest, Romania.

Sabău-Popa, D., \& Mara, R. (2015). Flexibility and Simplification of EU’ Financial Regulation in the Future Programming Period 2014-2020. Procedia Economics and Finance, 32(15), 15901597.

Secareanu, C. \& Tudorache, D. (2006). Finanţe publice, Finanţele firmei. Bucharest, Romania: Editura Universitară.

Tatoiu, A. (2008). Armonizarea sistemelor fiscale în contextual integrării în Uniunea Europenă. Cluj-Napoca, Romania: Editura Casa Cărţii de Ştiinţă.

Vacarel, I. (2006). Finanţe publice, Ediţia a V-a. Bucharest, Romania: Editura Didactică şi Pedagogică.

Voinea, G. (2005). Impozite, taxe şi contribuţii. Iași, Romania: Editura Junimea.

Wulf, C., Werker, J., Zapp, P., Schreiber, A., Schlör, H., \& Kuckshinrichs, W. (2018). Sustainable Development Goals as a Guideline for Indicator Selection in Life Cycle Sustainability Assessment. Procedia CIRP, 69, 59-65. 